\title{
Modification of Activated Carbon (Prepared From Flaxseed) With Fe304, Its Application As Adsorbent And Antibacterial
}

\section{H. Fekri ( $\sim$ m.h.fekri@abru.ac.ir)}

Ayatollah Borujerdi University https://orcid.org/0000-0002-1305-1902

S. Isanejad Mohamareh

Ayatollah Borujerdi University

M. Hosseini

Ayatollah Borujerdi University

M. Razavi Mehr

Ayatollah Borujerdi University

\section{Research Article}

Keywords: Adsorption, activated carbon (AC), Fe304, Cefazolin, Response Surface Methodology (RSM)

Posted Date: October 19th, 2021

DOl: https://doi.org/10.21203/rs.3.rs-972925/v1

License: (c) (i) This work is licensed under a Creative Commons Attribution 4.0 International License. Read Full License 


\title{
Modification of activated carbon (prepared from flaxseed) with $\mathrm{Fe}_{3} \mathrm{O}_{4}$, its application as adsorbent and antibacterial
}

\author{
M. H. Fekri*, S. Isanejad Mohamareh, M. Hosseini, M. Razavi Mehr
}

Department of Chemistry, Faculty of Basic Sciences, Ayatollah Borujerdi University, Borujerd, Iran.

*m.h.fekri@abru.ac.ir

\begin{abstract}
In this work, magnetic activated carbon (MGAC) was investigated to remove the antibiotic cefazolin from aqueous solutions as well as its antibacterial properties. To determine the optimal process conditions and achieve maximum efficiency, the effect of temperature, contact time, initial concentration of the drug, composite dosage, and $\mathrm{pH}$ using the response surface method (RSM) and the central composite design model (CCD) were investigated by DOE software. Structural characteristics and morphology of the nanocomposite were analyzed by using FTIR, XRD, EDAX, SEM, TEM, BET, TGA, VSM, analyzes. The results showed that $\mathrm{pH}=6$, the temperature of $30{ }^{\circ} \mathrm{C}$, contact time 150 minutes, initial concentration of drug 20 $\mathrm{mg} / \mathrm{l}$, and composite dosage $0.03 \mathrm{~g}$ were the best conditions for removing cefazolin from aqueous solution. In these conditions, the magnetically activated carbon was able to remove 96\% of cefazolin. The Langmuir, Freundlich, and Temkin isotherms were also studied and the results showed that the absorption behavior is most consistent with the Temkin isotherm. The results of thermodynamic experiments also showed that the adsorption process is exothermic and spontaneous. Finally, the antibacterial properties of the prepared nano composite on Streptococcus and Salmonella were investigated and the results showed that the prepared sample has antibacterial properties.
\end{abstract}

Keywords: Adsorption, activated carbon (AC), $\mathrm{Fe}_{3} \mathrm{O}_{4}$, Cefazolin, Response Surface Methodology (RSM)

\section{Introduction}

The presence of antibiotics, even in very small amounts in the environment, has various effects, the most important of which are low degradability, high toxicity, and their carcinogenic properties [1-3]. Cefazolin is an antibiotic from the group of cephalosporins and is a betalactam antibiotic with antibacterial activity (Fig. 1). It is used to treat infections caused by gram-positive and gram-negative bacteria [4].

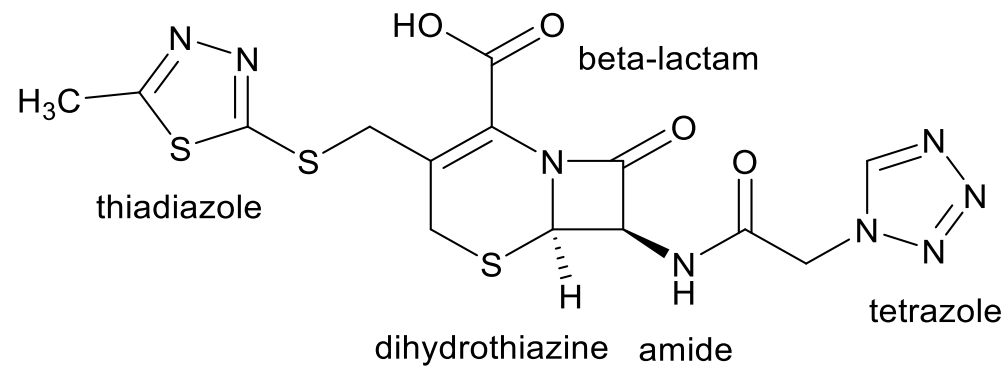

Fig. 1. Chemical structure of cefazolin. 
Purification and filtration of water and wastewater from various organic and medicinal pollutants are done in different ways. The most practical Purification methods include: biological purification, ultrasonic irradiation, Fenton oxidation, ozonation, electrochemical processes, photolysis, adsorption processes, and membrane processes that include reverse osmosis and ion exchange [5-10].

The adsorption process is the most suitable option for removing chemical contaminants and pharmaceutical compounds due to its high efficiency, easy design and implementation of the system, no production of by-products, and cost-effectiveness [11-17]. Removal and bioremediation of antibiotics are difficult due to the presence of the stable ring of naphthol as the main structure and its toxicity to microorganisms as well as their low biodegradability [18]. The adsorption process compared to other purification techniques in terms of initial cost, Effluent reuse, simplicity and flexibility in design, easy operation, and insensitivity to pollutants and toxic composition, have received more attention. Production of high-quality effluent and no formation of free radicals and hazardous substances are other advantages of this method [19]. Among the adsorbents used in this process, activated carbon is more common due to its high pore surface and volume and high adsorption capacity. Activated carbon is a completely amorphous solid with very high porosity. This material has a very high adsorption property and shows very good resilience. Adsorption on the activated carbon surface is mainly done physically, but chemical adsorption is also possible at high temperatures. Activated carbon mainly tends to absorb non-polar substances. During the activation process of activated carbon, functional groups are formed by oxygen and nitrogen on the surface and change their chemical properties. Activated carbon levels are generally hydrophobic and have a slightly negative charge and can be hydrophilized by an acid washing process. Activated carbon has many advantages as well as disadvantages [20].

One of its disadvantages is related to the separation of activated carbon from the liquid phase after the absorption of petroleum pollutants from water. The conventional method for separation from the liquid phase is filtration. But filtration causes the filters to clog and some activated carbon to be lost. So researchers are looking to find new ways to Separation of activated carbon from the liquid phase. One of these methods is to create a magnetic property in activated carbon and then easily separate it with a magnetic field [21-24]. To do this, activated carbon is mixed with magnetic nanoparticles, which uses this method.

\section{Experimental}

\subsection{Materials}

In this study, all used chemicals and reagents including Hexa Chloride Ferric $\left(\mathrm{FeCl}_{3} .6 \mathrm{H}_{2} \mathrm{O}\right)$, Tetrachloride Ferric $\left(\mathrm{FeCl}_{2} .4 \mathrm{H}_{2} \mathrm{O}\right)$, Sulfuric Acid $\left(\mathrm{H}_{2} \mathrm{SO}_{4}\right)$, Hydrochloric Acid $(\mathrm{HCl})$, Sodium Hydroxide $(\mathrm{NaOH})$, Zinc Chloride $\left(\mathrm{ZnCl}_{2}\right)$, Barium Chloride $\left(\mathrm{BaCl}_{2}\right)$ and 2,3, 5phenyltetrazolium chloride were in analytical grade and purchased from Merck Company. Cefazolin was obtained from the Food and Drug Administration of Iran. Agar Hinton Muller and Broth Hinton Muller were used to evaluating the antibacterial properties. 


\subsection{Preparation of magnetically activated carbon}

In this study, flaxseed waste was used to prepare carbon. EDAX analysis of flaxseed waste shows that it contains $47 \%$ carbon, which is cost-effective. To prepare activated carbon, the raw material was washed and placed in a laboratory for $24 \mathrm{~h}$. Then, it was placed in the oven at $105^{\circ} \mathrm{C}$ for 12 hours to dry completely. The dried material was crushed with the help of a mill and turned into fine particles (less than $4 \mathrm{~mm}$ ) and sieved $(50 \mu)$ to obtain fine and uniform particles. Weigh $30 \mathrm{~g}$ of the sifted powder and put it in the oven at $500{ }^{\circ} \mathrm{C}$ for 10 hours. Finally, leave at room temperature for $1 \mathrm{~h}$ to cool. To activate the carbon, the amount of carbon was mixed with zinc chloride in a ratio of [2: 1] and placed on a stirrer at $50{ }^{\circ} \mathrm{C}$ for $6 \mathrm{~h}$. The solution was passed through filter paper and the precipitate was washed several times with distilled water to bring the $\mathrm{pH}$ to about 5.6 to 7 . Finally, the activated carbon was placed in an oven at $105^{\circ} \mathrm{C}$ for 3 hours to dry [19]. $\mathrm{Fe}_{3} \mathrm{O}_{4}$ nanoparticles were deposited on the surface of activated carbon by in situ method [25].

The chemical reaction for the formation of magnetite nanoparticles is as follows:

$$
\begin{aligned}
& \mathrm{Fe}^{3+}+3 \mathrm{OH}^{-}=\mathrm{Fe}(\mathrm{OH})_{3}(\mathrm{~s}) \\
& \mathrm{Fe}(\mathrm{OH})_{3}(\mathrm{~s})=\mathrm{FeOOH}(\mathrm{s})+\mathrm{H}_{2} \mathrm{O} \\
& \mathrm{Fe} e^{2+}+2 \mathrm{OH}^{-}=\mathrm{Fe}(\mathrm{OH})_{2}(\mathrm{~s}) \\
& 2 \mathrm{FeOOH}(\mathrm{s})+\mathrm{Fe}(\mathrm{OH})_{2}(\mathrm{~s})=\mathrm{Fe}_{3} \mathrm{O}_{4}(\mathrm{~s})+2 \mathrm{H}_{2} \mathrm{O} \\
& \mathrm{Fe}^{2+}+2 \mathrm{Fe}^{3+}+8 \mathrm{OH}^{-}=2 \mathrm{Fe}(\mathrm{OH})_{3} \mathrm{Fe}(\mathrm{OH})_{2}(\mathrm{~s}) \rightarrow \mathrm{Fe}_{3} \mathrm{O}_{4}(\mathrm{~s})+2 \mathrm{H}_{2} \mathrm{O}
\end{aligned}
$$

If sample preparation is done in the air, $\mathrm{Fe}^{3+}$ oxidized to $\mathrm{Fe}^{2+}$, to prevent conversion $\mathrm{Fe}^{3+}$ to

$\mathrm{Fe}^{2+}$, from the neutral atmosphere and nitrogen gas conditions were used. $1.95 \mathrm{~g}$ of $\mathrm{FeCl}_{2} .4 \mathrm{H}_{2} \mathrm{O}$ and $3.9 \mathrm{~g}$ of $\mathrm{FeCl}_{3} .6 \mathrm{H}_{2} \mathrm{O}$ and $1.65 \mathrm{~g}$ of $\mathrm{AC}$ were added in a balloon under nitrogen gas conditions to completely dissolve the dissolved oxygen, then $50 \mathrm{ml}$ of sodium hydroxide. Concentrated $(5 \mathrm{M})$ was added dropwise to the contents of the balloon.

The addition of ammonia drop by drop reduces the diameter and size distribution of nanoparticles. The reaction mixture temperature was stirred at $90{ }^{\circ} \mathrm{C}$ for one hour by a magnetic stirrer. The resulting magnetic activated carbon, was rinsed several times with distilled water by magnetic decanting. Finally, the precipitate was placed in an oven at $60{ }^{\circ} \mathrm{C}$ for 5 hours to dry.

\subsection{Evaluation of MGAC nano composite performance in adsorption process}

After preparation of the nanocomposite, its function as an adsorbent in the removal of cefazolin from an aqueous medium was investigated. Then the optimal value of the parameters affecting the adsorption process was calculated using the data obtained from the software. Initially, 0.1 $\mathrm{g}$ of cefazolin powder was weighed and reached a volume of $100 \mathrm{ml}$. Then, the stock solution of cefazolin was prepared at a concentration of $1000 \mathrm{mg} / \mathrm{lit}$. Then, solutions with a concentration of 10-50 mg/lit were prepared using it. The maximum wavelength of cefazolin was obtained using a UV-Vis spectrometer (Fig. 2). 


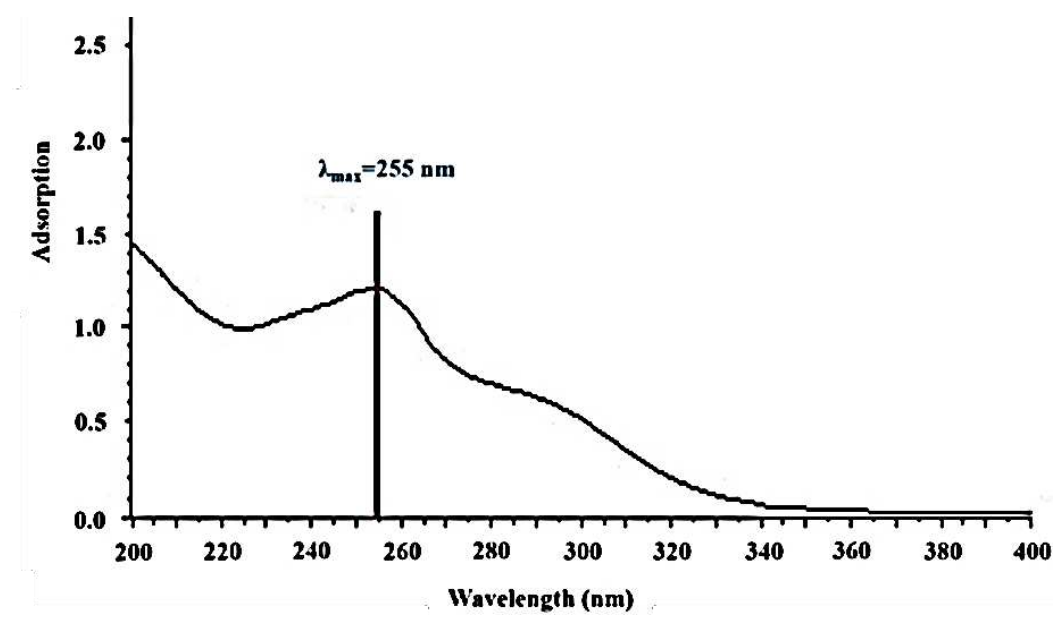

Fig. 2. UV-Vis spectrum to determine the maximum absorption of the antibiotic cefazolin.

To evaluate the amount of cefazolin absorbed by the composite, different concentrations of cefazolin solution were prepared and a calibration curve was drawn at $255 \mathrm{~nm}$ (Fig. 3).

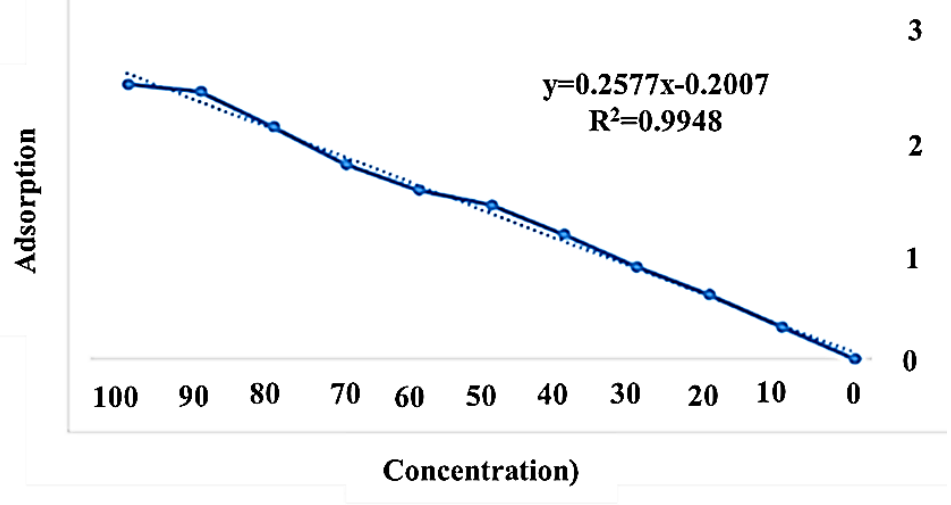

Fig. 3. Calibration curve of the antibiotic cefazolin.

\subsection{Effective factors in removing the antibiotic cefazolin}

In order to determine the effect of different parameters in the removal of cefazolin from aqueous solutions by MGAC, important parameters on the adsorption process such as temperature, contact time, $\mathrm{pH}$, initial concentration of the drug, and dosage of composite using Design Expert 11 software, The experiments were designed using the RSM response surface methodology based on the central CCD cube model. 5 levels were considered for each factor. In this type of leveling, the minimum and maximum values for the parameter are -2 and +2 , respectively (Table 1). According to the designed method, 50 experiments were performed with different amounts of effective factors (S1). The adsorbed contaminant concentration was measured using a UV device. The percentage of adsorption was calculated using the following formula:

$$
\mathrm{R} \%=\frac{\mathrm{C}_{0}-\mathrm{C}_{\mathrm{e}}}{\mathrm{C}_{0}} \times 100
$$

$\mathrm{C}_{0}$ and $\mathrm{C}_{\mathrm{e}}$ are the initial concentration and equilibrium concentration (mg/lit) of the drug and $\mathrm{R}$ is the percentage of the removed drug. 
Table 1. Effective factors of drug absorption by MGAC adsorbent (CCD design).

\begin{tabular}{|c|c|c|c|c|c|c|c|}
\hline factor (variable) & symbol & dimension & level -2 & level -1 & level 0 & level +1 & level +2 \\
\hline Temperature & $\mathrm{A}$ & ${ }^{\circ} \mathrm{C}$ & 30 & 40 & 50 & 60 & 70 \\
\hline Contact Time & $\mathrm{B}$ & $\mathrm{min}$ & 30 & 60 & 90 & 120 & 150 \\
\hline $\mathrm{pH}$ & $\mathrm{C}$ & - & 2 & 4 & 6 & 8 & 10 \\
\hline Init. Cons. Drug & $\mathrm{D}$ & $\mathrm{mg} / \mathrm{lit}$ & 10 & 20 & 30 & 40 & 50 \\
\hline Comp. Dosage & $\mathrm{E}$ & $\mathrm{g}$ & 0.01 & 0.02 & 0.03 & 0.04 & 0.05 \\
\hline
\end{tabular}

To obtain the $\mathrm{pH}_{\mathrm{pzc}}$ point, $10 \mathrm{ml}$ of water was adjusted to $\mathrm{pH} 2$ to 10 , then $0.01 \mathrm{~g}$ of adsorbent was added to each sample and placed on a magnetic stirrer for $1 \mathrm{~h}$. After filtering the samples, the $\mathrm{pH}$ was read. The relevant diagram was drawn and the $\mathrm{pH}_{\mathrm{pzc}}$ point was determined based on it. According to the diagram, the point $\mathrm{pH}_{\mathrm{pzc}}$ is 9 (Fig. 4). Due to the acidity of the adsorbent solution and its anionic, the tendency to be adsorbed at the positive level of the adsorbent is expected.

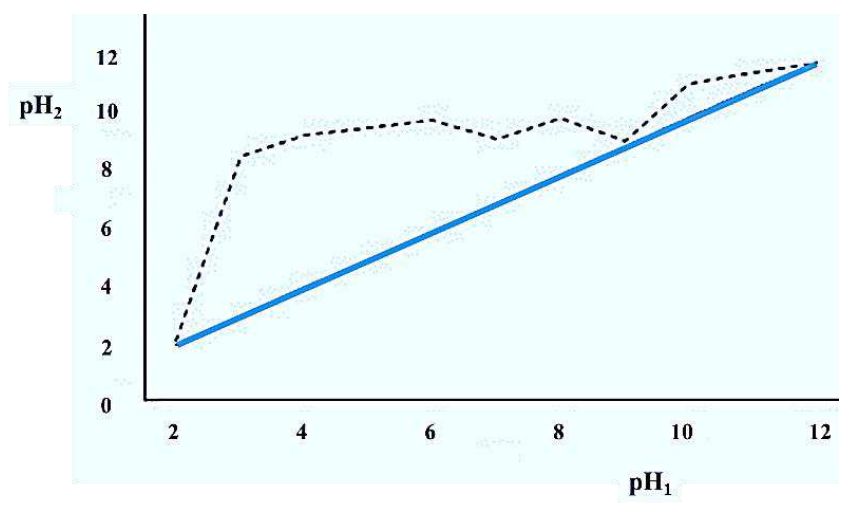

Fig. 4. Diagram for determining the $\mathrm{pH}_{\mathrm{pzc}}$.

\subsection{Design of Experiment (DOE) by RSM method}

Statistical analysis is used to determine the best model. For this purpose, 4 models were used, which are: Linear, 2FI, Quadratic, and Cubic. The appropriate model is based on the probability values of $p$ and the regression coefficients are the quadratic model (Table 2). In this work, all parameters, including composite dosage, initial concentration of drug, temperature, contact time, and $\mathrm{pH}$ have significant $\mathrm{p}$-values.

Table 2. Results of statistical analysis of the removal of cefazolin by MGAC adsorbent

\begin{tabular}{|c|c|c|c|c|c|}
\hline Source & $\begin{array}{c}\text { Sequential } \\
\mathrm{p} \text {-value }\end{array}$ & $\begin{array}{c}\text { Lack of Fit } \\
\mathrm{p} \text {-value }\end{array}$ & Adjusted $\mathbf{R}^{\mathbf{2}}$ & Predicted R $^{\mathbf{2}}$ & \\
\hline Linear & $<0.0001$ & $<0.0001$ & 0.5244 & 0.4407 & \\
\hline 2FI & 0.1654 & $<0.0001$ & 0.5771 & 0.6183 & \\
\hline Quadratic & $<\mathbf{0 . 0 0 0 1}$ & $\mathbf{0 . 9 1 5 1}$ & $\mathbf{0 . 9 9 9 5}$ & $\mathbf{0 . 9 9 9 2}$ & Suggested \\
\hline Cubic & 0.4024 & 0.9945 & 0.9995 & 0.9993 & Aliased \\
\hline
\end{tabular}




\subsection{Antibacterial properties of MGAC}

The McFarland modulus is universally used in Antibiotic Susceptibility Test (AST) to standardize the assessment number of bacteria in a liquid substance suspension or broth culture of the bacterial cell by divergence the turbidity of the cultured test suspension with that of the McFarland Standard. A 0.5 McFarland standard was accumulated by mixing $0.5 \mathrm{~mL}$ of $1.175 \%$ (w/v) barium chloride dihydrate $\left(\mathrm{BaCl}_{2} .2 \mathrm{H}_{2} \mathrm{O}\right)$-with $9.95 \mathrm{ml}$ of $1 \%(\mathrm{v} / \mathrm{v})$ sulfuric acid $\left(\mathrm{H}_{2} \mathrm{SO}_{4}\right)$. Mixing the two combinations forms a $\mathrm{BaSO}_{4}$ precipitate, which causes darkness in the solution. The resulting $0.5 \mathrm{McFarland}$ suspension has an optical absorption of 0.08-0.13 at $625 \mathrm{~nm}$. This turbidity was equivalent to approximately $1.8 \times 10^{8}(\mathrm{cfu} / \mathrm{ml})$.

Bacteria must be activated 24 hours prior to preparation for microbial cultures after which the multiplication method was used. To study bacterial strain the following procedure is pursued every bacterium: The bacterium was harvested by sterile swab from a standard bacterial medium, next to the flame, and on the disinfected workbench. Then, the impregnated swab was contacted on a plate, on which the name of microbes has been previously labeled, in parallel lines in three orientations (vertical, horizontal, diagonal) so that the entire surface of the plate is covered by a single layer of the bacterium. Finally, plates were incubated for 24 hours.

$3000 \mu \mathrm{g} \mathrm{mL}^{-1}$ fresh stock MGAC nanocomposite solution was prepared in sterile dimethylsulfoxide (DMSO) solution. The fresh working solutions of MGAC nanocomposite with concentrations of $1000,500,250,125,62,31.25,62.15,7.81$, and $3.90 \mu \mathrm{g} \mathrm{mL}^{-1}$ were prepared appropriately diluted 9 times.

The concentration of $1000 \mu \mathrm{g} \mathrm{mL}^{-1}$ of imipenem was applied as a positive control for gramnegative and gram-positive bacteria. Also, $100 \mu \mathrm{L}$ of DMSO as a negative control was added to each well.

First, $3000 \mu \mathrm{g} \cdot \mathrm{mL}^{-1}$ of MGAC nanocomposite was prepared in DMSO solvent. Then, the stock solution was diluted 9 times (in serial 2-fold dilutions) and solutions with 1000, 500, 250, 125 , $62,31.25,15.62,7.81$ and $3.90 \mu \mathrm{g} . \mathrm{mL}^{-1}$ concentrations were obtained. To develop the microbial suspension, first, microbial strains were subcultured in sterile Mueller-Hinton Broth (MHB) and incubated to a turbidity of $0.5 \mathrm{McF}$ arland standard, then were diluted in the ratio $1: 150$ to reach the final number of $1.5 \times 10^{8} \mathrm{cfu}^{\mathrm{mL}} \mathrm{m}^{-1}$. Based on the number of bacterial strains, a 96-well microplate, arranged in 8 rows with 12 columns, containing broth medium and microbial agents at serial concentrations was set up for each bacterium. The wells of each row were numbered from 1 to 12 . The value of $100 \mu \mathrm{L}$ of $1000 \mu \mathrm{g} / \mathrm{mL}^{-1}$ nanocomposite was added in well 1 . Then $100 \mu \mathrm{L}$ of microbial suspension was added to wells 2-12. Finally, the inoculated tubes were covered and incubated at temperatures of $37^{\circ} \mathrm{C}$ for 24 hours. After incubation, the tubes were surveyed for turbidity caused by inoculated bacterial growth. The 2, 3, 5-triphenyltetrazolium chloride salt was used as a visual indicator well showing pink-colored microbial growth. MIC values were defined as the lowest concentration of MGAC nanocomposite that inhibited visible growth.

\section{Results and discussion}

\subsection{Characterization of MGAC}

Fig. 4a shows the XRD patterns of $\mathrm{Fe}_{3} \mathrm{O}_{4} / \mathrm{AC}$ nanocomposite. The XRD spectrum of MGAC shows a broad peak in the range of $2 \Theta=20-30$, indicating the presence of amorphous activated carbon. The peaks in $2 \Theta=31$ and 57 confirm the cubic structure of $\mathrm{Fe}_{3} \mathrm{O}_{4}$. Also, the peak at $2 \Theta=22$ can be assigned to $\alpha-\mathrm{Fe}_{3} \mathrm{O}_{4}$. The obtained peaks are in accordance with the standard sample peaks and the presence of activated carbon and $\mathrm{Fe}_{3} \mathrm{O}_{4}$ particles are confirmed [26]. 
The FTIR spectra of the MGAC composite are shown in Fig. 5b. In the spectra of MGAC, the broad bond that was seen in the $3431 \mathrm{~cm}^{-1}$ are related to the hydroxyl tensile vibration $(-\mathrm{OH})$, which is due to intramolecular hydrogen bonding. When there is hydrogen bonding, the adsorption of $\mathrm{C}=\mathrm{O}$ is transferred to a lower frequency. Also, the bonds at $\approx 1380, \approx 1530$, and $\approx 1340 \mathrm{~cm}^{-1}$ are attributed to $\mathrm{C}-\mathrm{C}$ and the $\mathrm{C}-\mathrm{O}$. The observed bond at $\approx 1630 \mathrm{~cm}^{-1}$ is related to the $\mathrm{C}=\mathrm{C}$ vibrations. The peaks at 571 and $432 \mathrm{~cm}^{-1}$ are also assigned to the presence of nanoparticles of $\mathrm{Fe}_{3} \mathrm{O}_{4}$.

The morphology and surface properties of MGAC adsorbents were investigated using SEM imaging (Fig. 5c). Fig. 5c shows the presence of two phases of activated carbon (dark spots) and $\mathrm{Fe}_{3} \mathrm{O}_{4}$ (bright spots). This image shows that the adsorbent has a porous structure and a plate. The images also show that the size of the pores is in the range of 2-50 nm, so the prepared nanocomposite pores are of the mesoporous type.

The TEM image (Fig. 5d) shows that there is no accumulation in the nanoparticles and the $\mathrm{Fe}_{3} \mathrm{O}_{4}$ nanoparticles are evenly distributed on the surface of the activated carbon, which confirms the success of the nanocomposite synthesis.
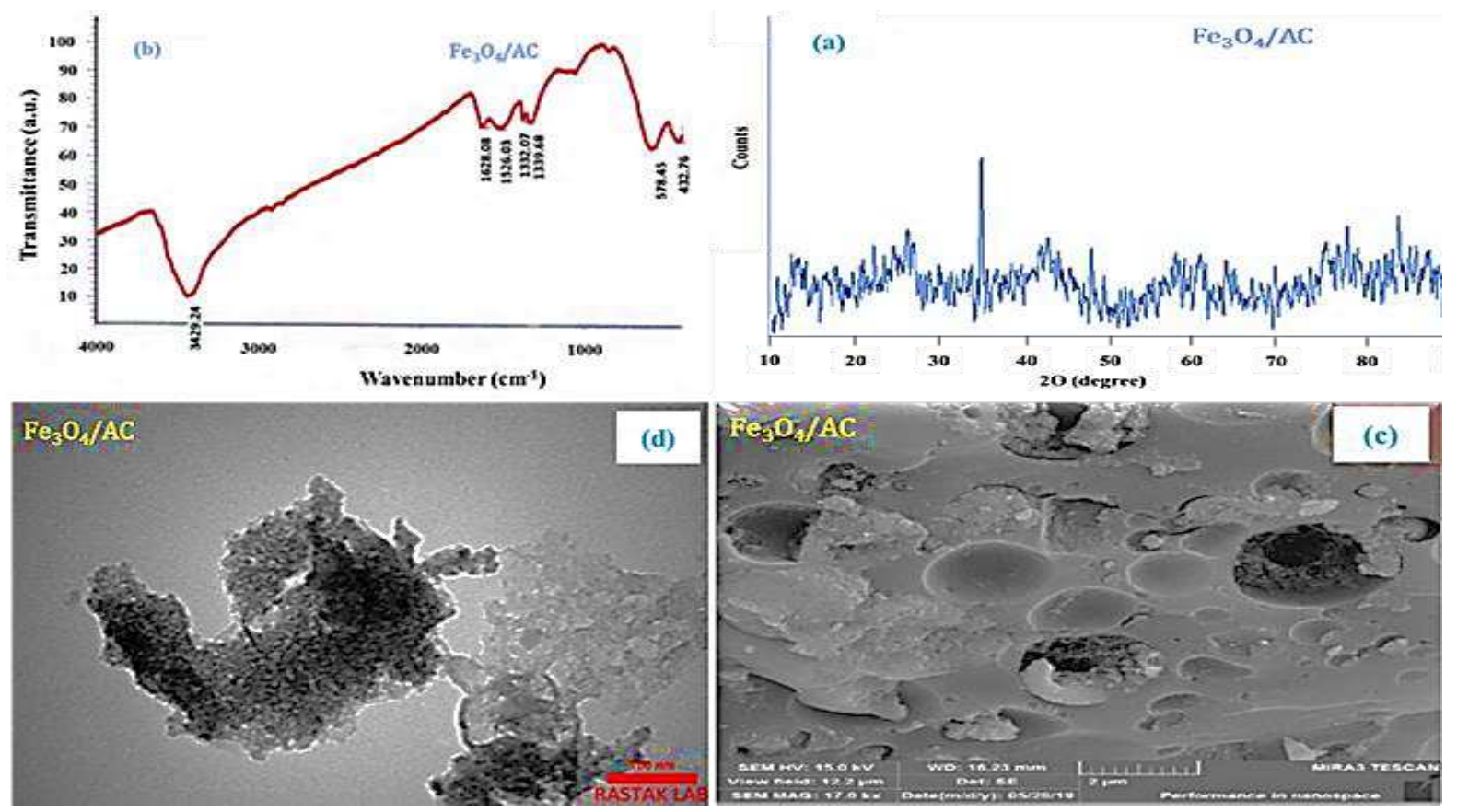

Fig. 5. a) XRD spectra b) FT-IR Spectra c) SEM micrographs and d) TEM image of MGAC.

The data obtained from BET analysis show that the specific area of activated carbon is 157.53 $\mathrm{m}^{2} / \mathrm{g}$. Also, the volume of pores and the average diameter of nanoparticles were reported as $0.4343 \mathrm{~cm}^{3} / \mathrm{g}$ and $3.4099 \mathrm{~nm}$, respectively. Therefore, it can be concluded that the prepared nanocomposite is of mesoporous type.

EDX elemental (Fig. 6) shows the presence of $\mathrm{C}, \mathrm{O}, \mathrm{Na}, \mathrm{Mg}, \mathrm{Cl}$, and $\mathrm{Fe}$ atoms in the structure of nanocomposite $\left(\mathrm{Fe}_{3} \mathrm{O}_{4} / \mathrm{AC}\right)$, which confirms the formation of nanocomposites with impurities. The presence of $\mathrm{Mg}$ and $\mathrm{Cl}$ elements may be related to activated carbon impurities. The presence of $\mathrm{Na}$ may also be related to the use of concentrated $\mathrm{NaOH}(5 \mathrm{M})$ in the placement of $\mathrm{Fe}_{3} \mathrm{O}_{4}$ nanoparticles on the activated carbon surface. 


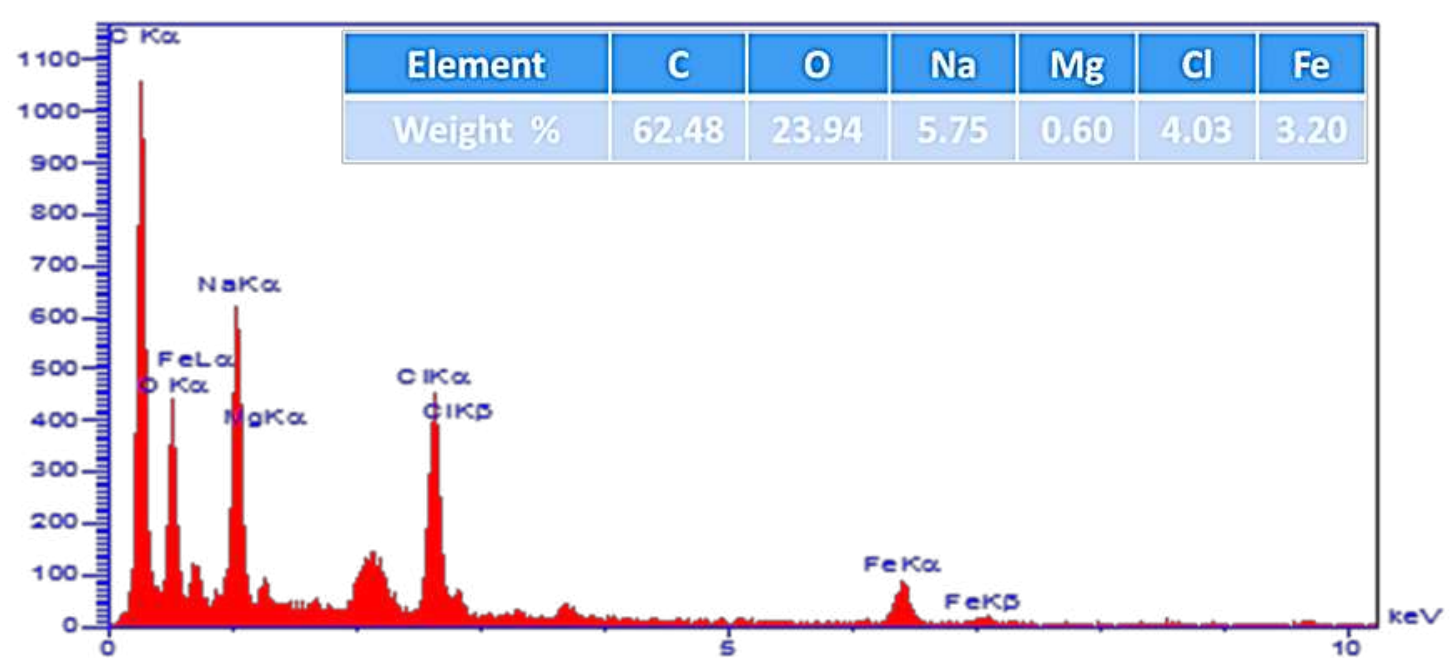

Fig. 6. EDAX spectra of MGAC.

The magnetic properties of the adsorbent were investigated using a vibrating magnetometer. Figure 7 shows the hysteresis curve of the prepared adsorbent. The test results show that by removing the magnetic field, the magnetic property of the adsorbent is reduced to zero, which confirms its superparamagnetic property. Also, the presence of a narrow hysteresis ring has a small number of ferromagnetic properties. The magnetic property of $\mathrm{Fe}_{3} \mathrm{O}_{4}$ nanoparticles is $6.89 \mathrm{~A} . \mathrm{m}^{2} / \mathrm{Kg}$, which is slightly reduced by activated carbon, and the maximum saturation magnetization for the adsorbent is $6.51 \mathrm{~A} \cdot \mathrm{m}^{2} / \mathrm{kG}$. Also, the distribution efficiency of $\mathrm{Fe}_{3} \mathrm{O}_{4}$ nanoparticles in activated carbon substrate is $94.69 \%$.

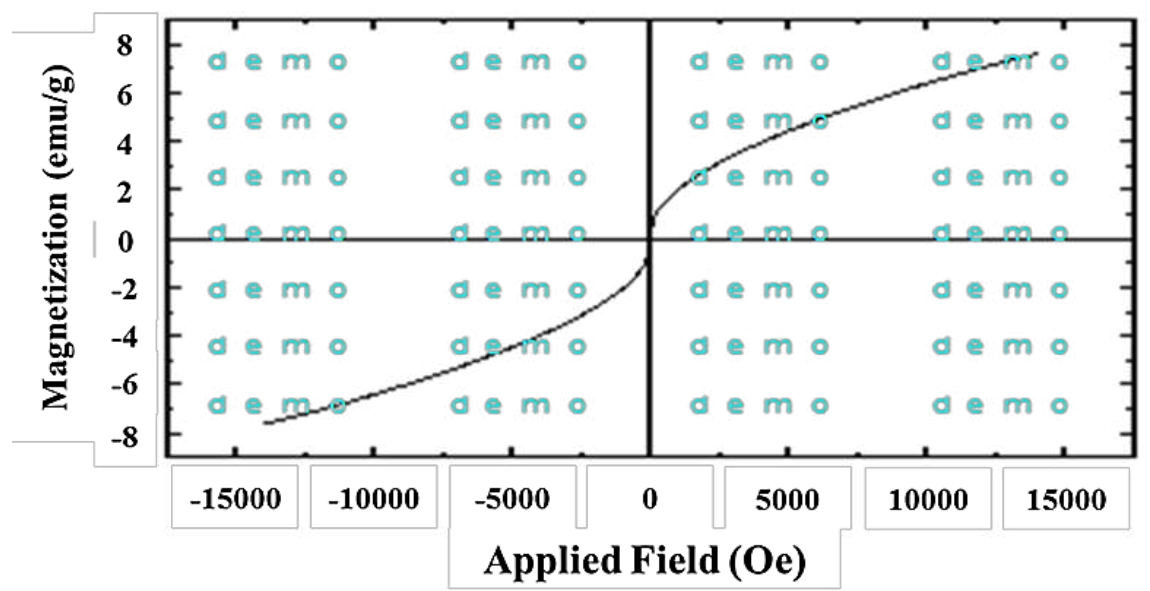

Fig. 7. The hysterical curve for MGAC magnetic measurement.

Figure 8 is a thermal analysis of magnetic activated carbon, with a blue diagram for TGA and a green diagram for DTG from 25 to $900{ }^{\circ} \mathrm{C}$. The obtained spectrum shows that the MGAC has good thermal stability properties, because it can withstand very high temperatures. In this spectrum, three steps (stages) of weight loss can be seen. In the first step, up to $151{ }^{\circ} \mathrm{C}, 13.5 \%$ of the total weight is lost, which can be attributed to the moisture in the sample. The second stage, which begins at a temperature of about $300{ }^{\circ} \mathrm{C}(\mathrm{Td})$, involves the decomposition of the remaining organic compounds in the sample (cellulose and hemicellulose), with a weight loss 
of $23 \%$ of the total weight. At temperatures above $700{ }^{\circ} \mathrm{C}$, oxidation of the elements in the sample occurs, which is mainly related to carbon.

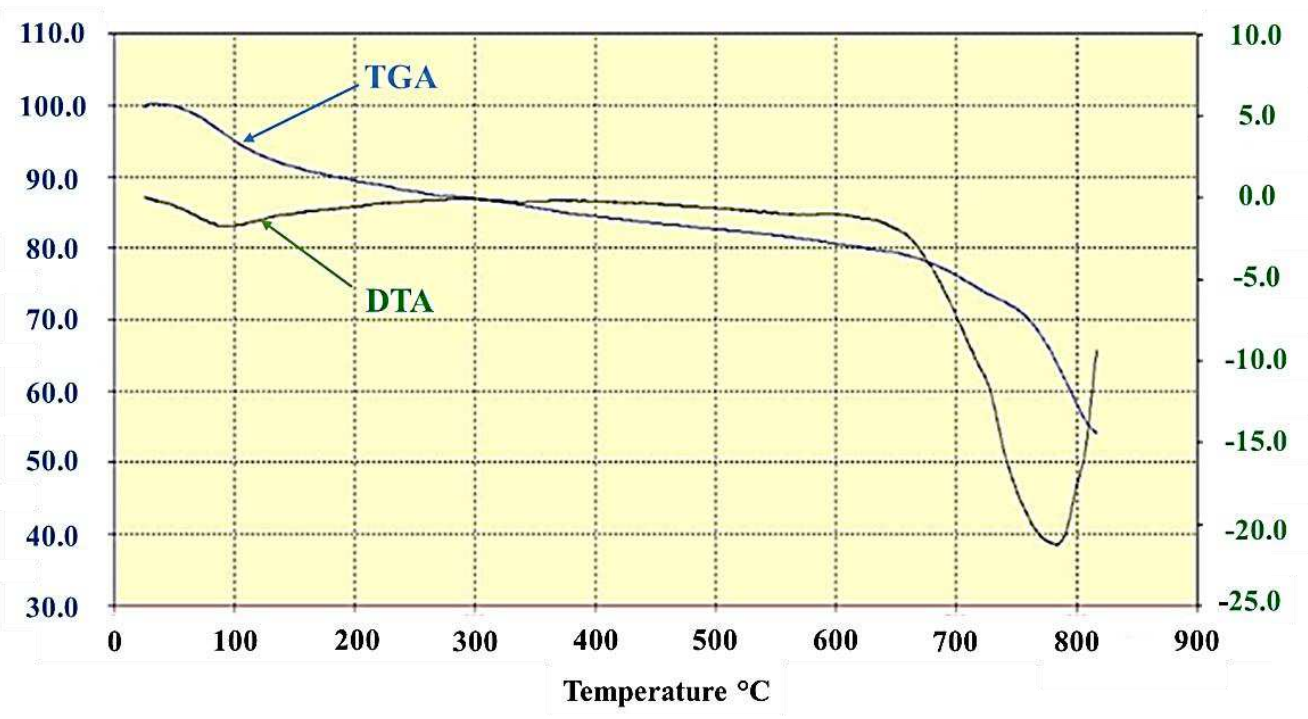

Fig. 8. MGAC thermal gravimetric diagram.

\subsection{Absorption-desorption diagram}

The nitrogen adsorption-desorption isotherm in Fig. 9a shows that the mesoporous materials do not overlap in the sweep. That is, the absorption diagram does not match the absorption diagram, and various factors can be the reason for this. These factors include the shape of the cavities, the structure of the material, the method of material production, and the physical purity of the material. In Figure 9a, the beginning and end of the hysteresis ring show that the cavities are cylindrical. Also, the volume of micro-cavities and meso-cavities is done using t-plot modes, and the distribution of cavities in meso-cavities is studied by the BJH method. The BJH diagram shows that the highest distribution occurred in the range of 1-10 nm (Fig. 5b).
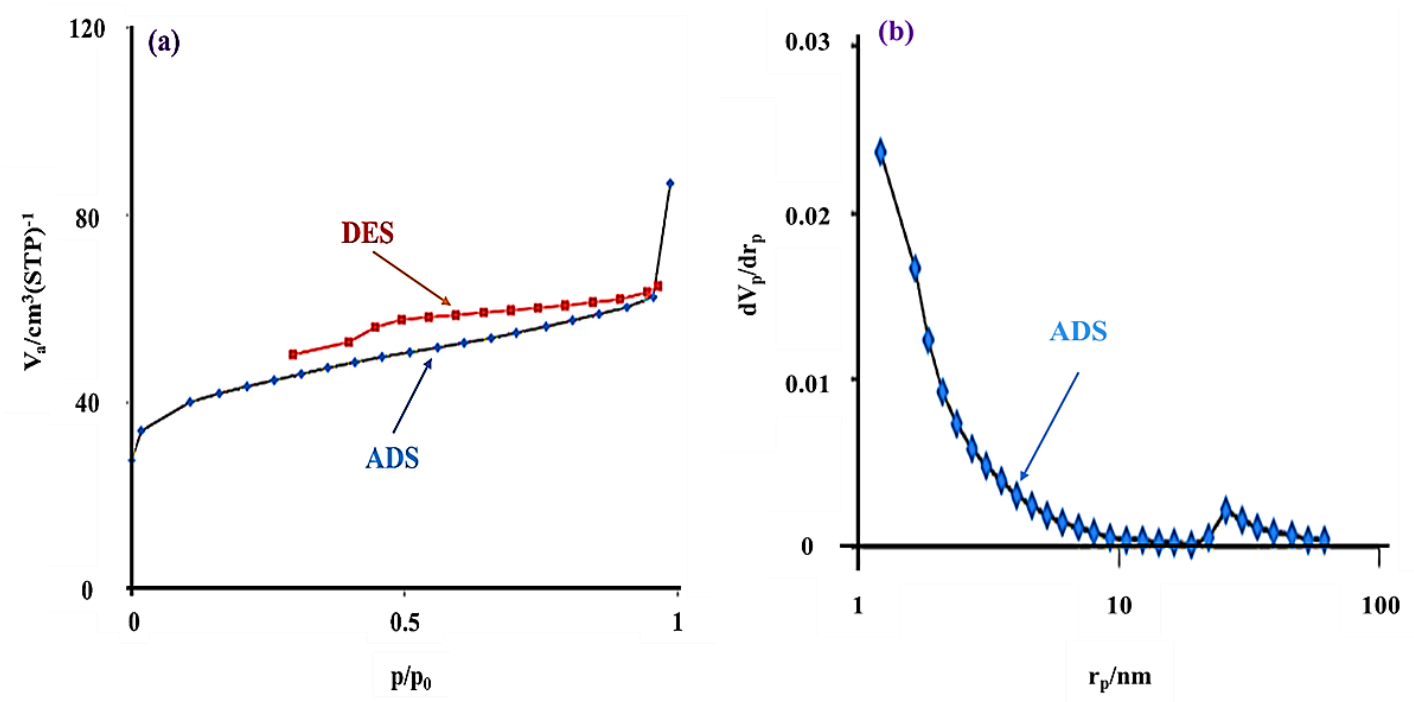

Fig. 9. a) Adsorption/desorption isotherm and b) BJH-plot. 


\subsection{Statistical analysis}

Based on the results in table 3, all parameters are significant in linear mode and the probability p-values are less than 0.05. Equation 7 showed the effective factors and their contribution to the removal of cefazolin. The equation in terms of coded factors can be used to predict the response for certain levels of each factor. By default, the upper levels of the invoices are encoded +1 and the lower levels are encoded -1 . The coded equation is useful for comparing the relative effect of factors by comparing factor coefficients.

$\% \mathrm{DE}($ Cefazolin $)=+30.58+9.30 \mathrm{~A}-0.1500 \mathrm{~B}+6.35 \mathrm{C}-2.14 \mathrm{D}+4.05 \mathrm{E}+0.5625 \mathrm{AB}$

$0.0625 \mathrm{AC}-3.69 \mathrm{AD}-1.00 \mathrm{AE}-2.69 \mathrm{BC}+3.06 \mathrm{BD}+0.0000 \mathrm{BE}+0.5625 \mathrm{CD}-3.00 \mathrm{CE}$ $+1.50 \mathrm{DE}-0.0300 \mathrm{~A}^{2}+8.84 \mathrm{~B}^{2}+0.8450 \mathrm{C}^{2}-3.64 \mathrm{D}^{2}-1.53 \mathrm{E}^{2}$

Table 3. Results of analysis of variance (ANOVA) removal of cefazolin by MGAC adsorbent

\begin{tabular}{|c|c|c|c|c|c|c|}
\hline Source & Sum of Squares & Df & Mean Square & F-value & p-value & \\
\hline Model & 10318.14 & 20 & 515.91 & 4953.74 & $<0.0001$ & Significant \\
\hline A-pH & 3459.60 & 1 & 3459.60 & 33219.12 & $<0.0001$ & \\
\hline B-temp. & 0.9000 & 1 & 0.9000 & 8.64 & 0.0064 & \\
\hline C-cont. time & 1612.90 & 1 & 1612.90 & 15487.09 & $<0.0001$ & \\
\hline D-init. conc. & 184.04 & 1 & 184.04 & 1767.16 & $<0.0001$ & \\
\hline E-AFC dose & 656.10 & 1 & 656.10 & 6299.88 & $<0.0001$ & \\
\hline $\mathrm{AB}$ & 10.13 & 1 & 10.13 & 97.22 & $<0.0001$ & \\
\hline $\mathrm{AC}$ & 0.1250 & 1 & 0.1250 & 1.20 & 0.2823 & \\
\hline $\mathrm{AD}$ & 435.13 & 1 & 435.13 & 4178.08 & $<0.0001$ & \\
\hline $\mathrm{AE}$ & 32.00 & 1 & 32.00 & 307.26 & $<0.0001$ & \\
\hline $\mathrm{BC}$ & 231.13 & 1 & 231.13 & 2219.27 & $<0.0001$ & \\
\hline $\mathrm{BD}$ & 300.12 & 1 & 300.12 & 2881.80 & $<0.0001$ & \\
\hline $\mathrm{BE}$ & 0.0000 & 1 & 0.0000 & 0.0000 & 1.0000 & \\
\hline $\mathrm{CD}$ & 10.12 & 1 & 10.12 & 97.22 & $<0.0001$ & \\
\hline $\mathrm{CE}$ & 288.00 & 1 & 288.00 & 2765.38 & $<0.0001$ & \\
\hline $\mathrm{DE}$ & 72.00 & 1 & 72.00 & 691.34 & $<0.0001$ & \\
\hline $\mathrm{A}^{2}$ & 0.0288 & 1 & 0.0288 & 0.2765 & 0.6030 & \\
\hline $\mathrm{B}^{2}$ & 2503.49 & 1 & 2503.49 & 24038.53 & $<0.0001$ & \\
\hline $\mathrm{C}^{2}$ & 22.85 & 1 & 22.85 & 219.39 & $<0.0001$ & \\
\hline $\mathrm{D}^{2}$ & 424.57 & 1 & 424.57 & 4076.72 & $<0.0001$ & \\
\hline $\mathrm{E}^{2}$ & 74.91 & 1 & 74.91 & 719.28 & $<0.0001$ & \\
\hline Residual & 3.02 & 29 & 0.1041 & & & \\
\hline Lack of Fit & 1.81 & 22 & 0.0821 & 0.4727 & 0.9151 & not significant \\
\hline Pure Error & 1.21 & 7 & 0.1736 & & & \\
\hline Cor Total & 10321.16 & 49 & & & & \\
\hline
\end{tabular}


Fig. 10a shows the predicted values versus actual values. The actual values obtained are very close to the predicted values, and this shows the accuracy of the results and shows a low deviation from the diagonal line. Fig. 10b shows the values of the standard residual values versus the actual values of the model. In this diagram, the distribution of the responses of the 50 experiments performed can be seen. Given that all the runs are in the defined confidence range $(-4$ to +4$)$, the correlation of the model with the obtained runs can be confirmed.
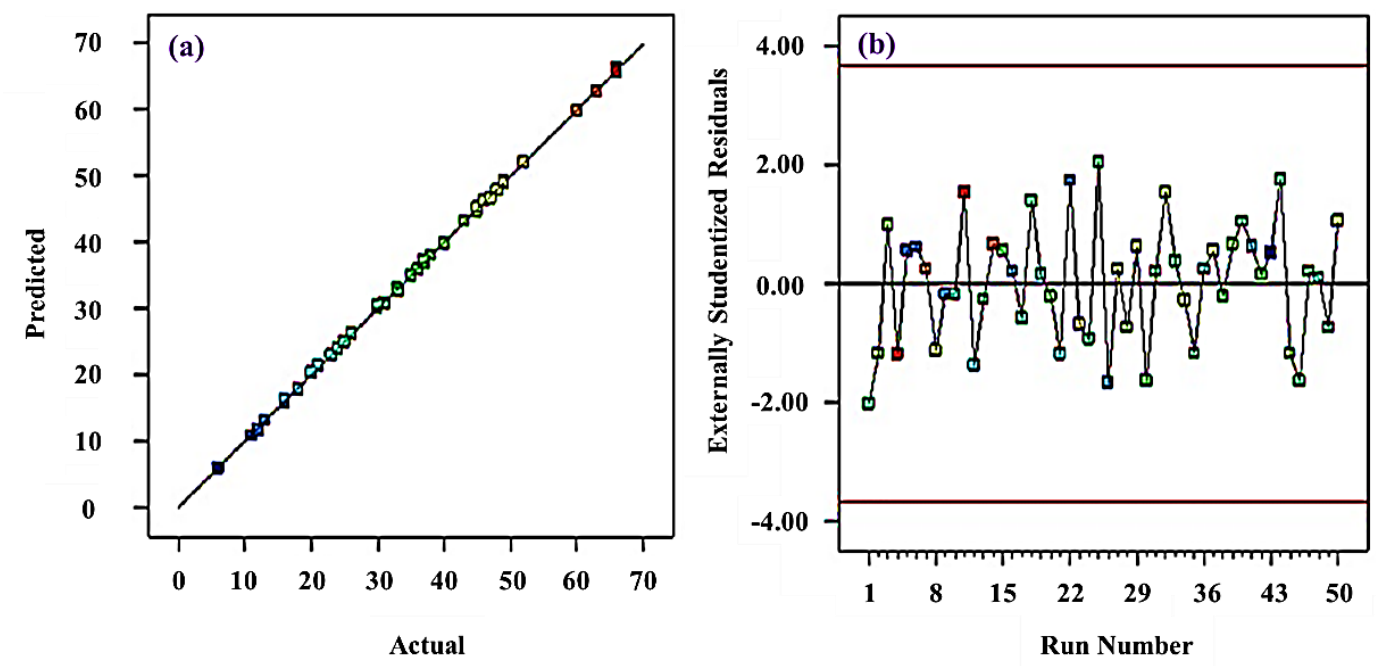

Fig. 10. a) Predicted vs. Actual and b) Residuals vs. Run.

In order to investigate the effect of $\mathrm{pH}$ in this work, $\mathrm{pH}$ values in the range of 2-10 were examined. As a significant parameter, $\mathrm{pH}$ has a positive impact on the efficiency of removal of the drug (Fig. 11a). When the $\mathrm{pH}$ ranges from 2 to 10. The highest amount of drug was absorbed in $\mathrm{pH}=6$. Cefazolin has a positive charge at $\mathrm{pH}<9\left(\mathrm{pH}_{\mathrm{pzc}}\right)$ while the nanocomposite surface has a negative charge therefore the optimum $\mathrm{pH}$ for cefazolin is in $\mathrm{pH}=6$. A repulsive force is created between the drug and the nanocomposite and the adsorption increases at $\mathrm{pH}<9$. Also, the chemical structure of the cefazolin drug includes electron-rich aromatic rings, which perfectly absorb the positive surface of the prepared adsorbent and increase the adsorption.

To study the effect of temperature on the process of removal of cefazolin from aqueous solutions by MGAC adsorbent and its optimization, a range of $30-70{ }^{\circ} \mathrm{C}$ has been considered. Fig. $11 \mathrm{~b}$ shows that the maximum absorption occurred at $30{ }^{\circ} \mathrm{C}$. With decreasing temperature, the rate of diffusion of cefazolin ions on the adsorbent surface of MGAC increases and the reason can be attributed to the decrease in kinetic energy of cefazolin ions and the increase of active sites of the adsorbent surface at lower temperatures.

Another factor that affects the percentage of adsorption is the contact time. The effect of contact time in the range of 30-150 minutes was investigated (Fig. 11c). In this study, the optimal contact time for absorption is 150 minutes. The increase in the adsorption percentage with the contact time is probably due to the greater opportunity to perform surface adsorption.

The effect of the initial concentration of cefazolin in the adsorption process by MGAC and obtaining its optimal point, different concentrations of cefazolin in the range of $10-50 \mathrm{mg} / \mathrm{l}$ were considered. The results in Fig. 11d showed that the optimal amount of adsorption is related to the concentration of $20 \mathrm{mg} / \mathrm{l}$. The reason for the increase in adsorption at lower 
concentrations may be that more active sites are provided to the adsorbent and the performance of the adsorption process is increased.

Finally, the effect of the amount of adsorbent on the removal of cefazolin from aqueous solutions in the range of 0.01-0.05 $\mathrm{g}$ was investigated to obtain the optimal amount of adsorbent, because adding too much adsorbent is not economically viable and also extends the mixing time of the solution and the adsorbent. The results show the optimal amount of adsorbent $0.03 \mathrm{~g}$. Fig. 11e shows that increasing the amount of adsorbent has a positive effect on adsorption performance. It then reaches a constant value, which can be attributed to the adsorption of all adsorbed molecules (cefazolin) in solution or the saturation of the pores of the adsorbent surface.

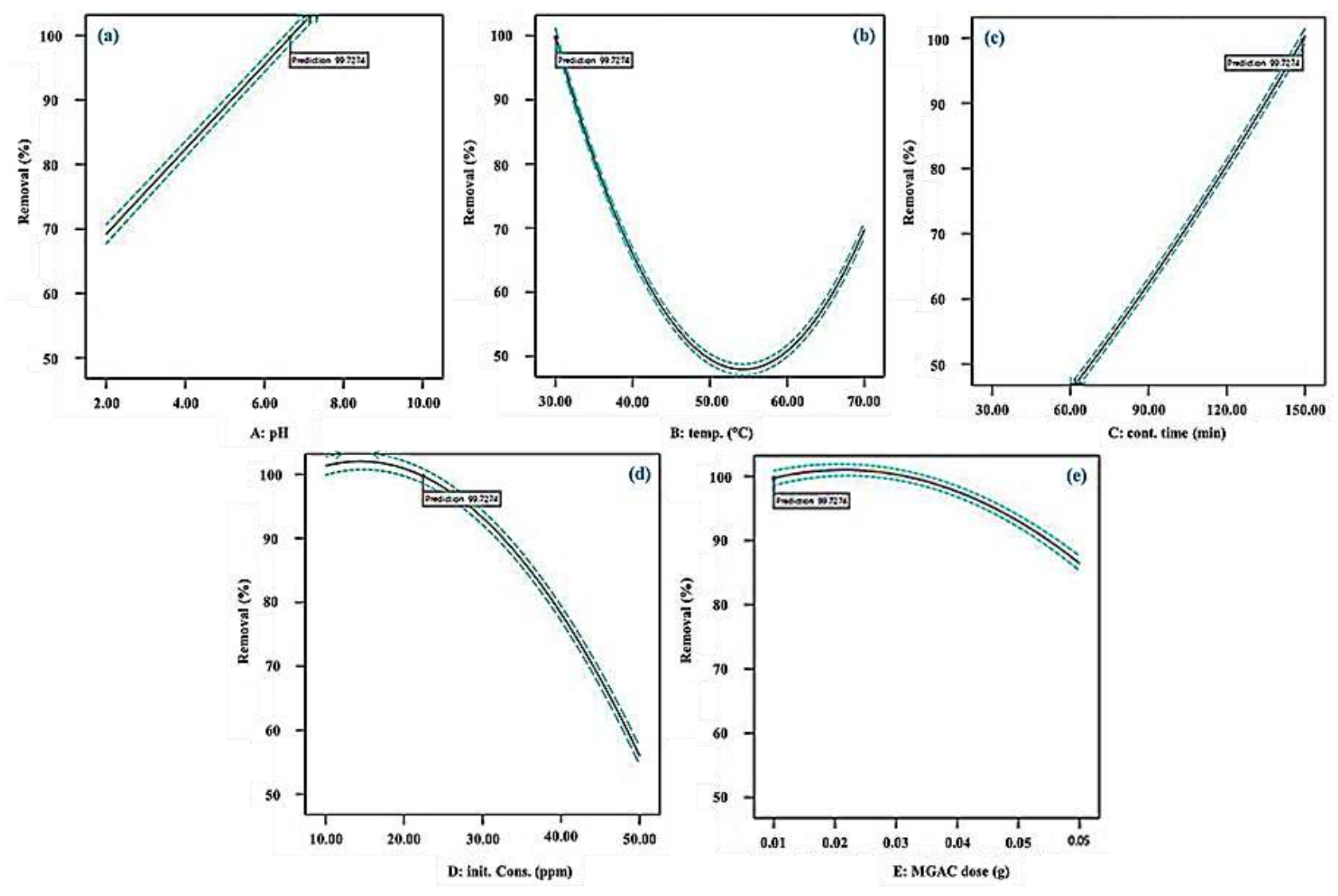

Fig. 11. The effect of different factors on the adsorption of cefazolin.

\subsection{Investigation of adsorption isotherms}

In this study, Langmuir, Freundlich and Temkin isotherms were investigated under optimal conditions $\left(\mathrm{pH}=6\right.$, temp. $=30{ }^{\circ} \mathrm{C}$, cont. time $=150 \mathrm{~min}$., init.cons. drug $=20 \mathrm{mg} / \mathrm{l}$ and comp. dose $=0.03 \mathrm{~g})$.

In the Langmuir isotherm, adsorption is monolayer and its equation is as follows:

$$
\frac{1}{q_{e}}=\left(\frac{1}{q_{m} K_{L}}\right) \frac{1}{C_{e}}+\frac{1}{q_{m}}
$$

Where $\mathrm{q}_{\mathrm{e}}$, is the concentration of the adsorbed drug in $\mathrm{mg} \mathrm{g}^{-1}$ at any moment, $\mathrm{q}_{\max }$, is the maximum adsorption capacity the adsorbent in $\mathrm{mg} \mathrm{g}^{-1}$. The equilibrium constant $k_{L}$, which 
depends on the amount of adsorbent-adsorbate tendency, and $\mathrm{C}_{\mathrm{e}}$ is the concentration of equilibrium drug or not absorbed in $\mathrm{mg} \mathrm{g}^{-1}$.

The Dimension Index $\left(R_{l}\right)$ is also used to test the usability of the Langmuir equation and is expressed as (9).

$$
\mathrm{R}_{L}=\frac{1}{1+b C_{0}}
$$

Where $\mathrm{C}_{0}$ is the initial concentration of the solution and $\mathrm{b}$ is the Langmuir constant. If the value is $\mathrm{R}_{L}>0$, model is inappropriate, if $\mathrm{R}_{L}=1$, is appropriate as the linear model, if $0<\mathrm{R}_{L}<1$, the model is suitable and if $R_{L}=0$, the model is inefficient [27].

The Freundlich isotherm is used to identify the characteristics of a heterogeneous system and its relationship is as follows:

$$
\begin{aligned}
& q_{e}=k_{F} \cdot C_{e}^{\frac{1}{n}} \\
& \log q_{e}=\log k_{F}+\frac{1}{n} \log C_{e}
\end{aligned}
$$

Where $\mathrm{q}_{\mathrm{e}}$ and $\mathrm{C}_{\mathrm{e}}$ are the same as those mentioned in the Langmuir relationship. $\mathrm{kf}_{\mathrm{f}}$ and $\mathrm{n}$ are the Freundlich model constants, which represent adsorption capacity and absorption intensity respectively.

The equation of obedience Temkin isotherm is expressed as follows:

$$
\begin{aligned}
& q_{e}=\frac{R T}{b} \ln \left(K_{T} C_{e}\right) \\
& b=\frac{R T}{B} \rightarrow q_{e}=\mathrm{Bln}_{\mathrm{e}}+\mathrm{Bln}_{\mathrm{T}}
\end{aligned}
$$

In this relation, the constant without dimension $\mathrm{B}$ is proportional to the heat of surface adsorption. $\mathrm{K}_{\mathrm{T}}$ is the Temkin isotherm constant in $\operatorname{~g}^{-1}$. By plotting $\ln \mathrm{C}_{\mathrm{e}}$ versus $\ln \mathrm{q}_{\mathrm{e}}$ and using the slope and width of the origin, the values $B$ and $\ln K_{T}$ can be calculated.

The regression coefficient $\left(\mathrm{R}^{2}\right)$ of the Langmuir isotherm is higher than that of the Freundlich and Temkin isotherm coefficients. We conclude that the Langmuir isotherm is more consistent with the results of this study. 
Table 5. Isotherm parameters were obtained from Langmuir, Freundlich, and Temkin models for encapsulation of efficiency by nanocarrier $\mathrm{Fe}_{3} \mathrm{O}_{4} / \mathrm{AC}$ at optimized temperature.

\begin{tabular}{ccccccccc}
\hline \multicolumn{3}{c}{ Langmuir isotherm } & \multicolumn{3}{c}{ Freundlich isotherm } & \multicolumn{3}{c}{ Temkin isotherm } \\
\hline $\mathrm{q}_{\mathrm{m}}(\mathrm{mg} / \mathrm{g})$ & $\mathrm{b}(\mathrm{L} / \mathrm{mg})$ & $\mathrm{R}^{2}$ & $\mathrm{n}$ & $\mathrm{k}_{\mathrm{F}}\left(\mathrm{mg}^{1-(1 / \mathrm{n})} \mathrm{L}^{1 / \mathrm{n}} \mathrm{g}^{-1}\right)$ & $\mathrm{R}^{2}$ & $\mathrm{~B}$ & $\mathrm{~K}_{\mathrm{T}}$ & $\mathrm{R}^{2}$ \\
\hline 123.46 & 0.53 & $\mathbf{0 . 9 6 2 2}$ & 3.54 & 44.46 & 0.7149 & 15.73 & 22.42 & 0.7629
\end{tabular}

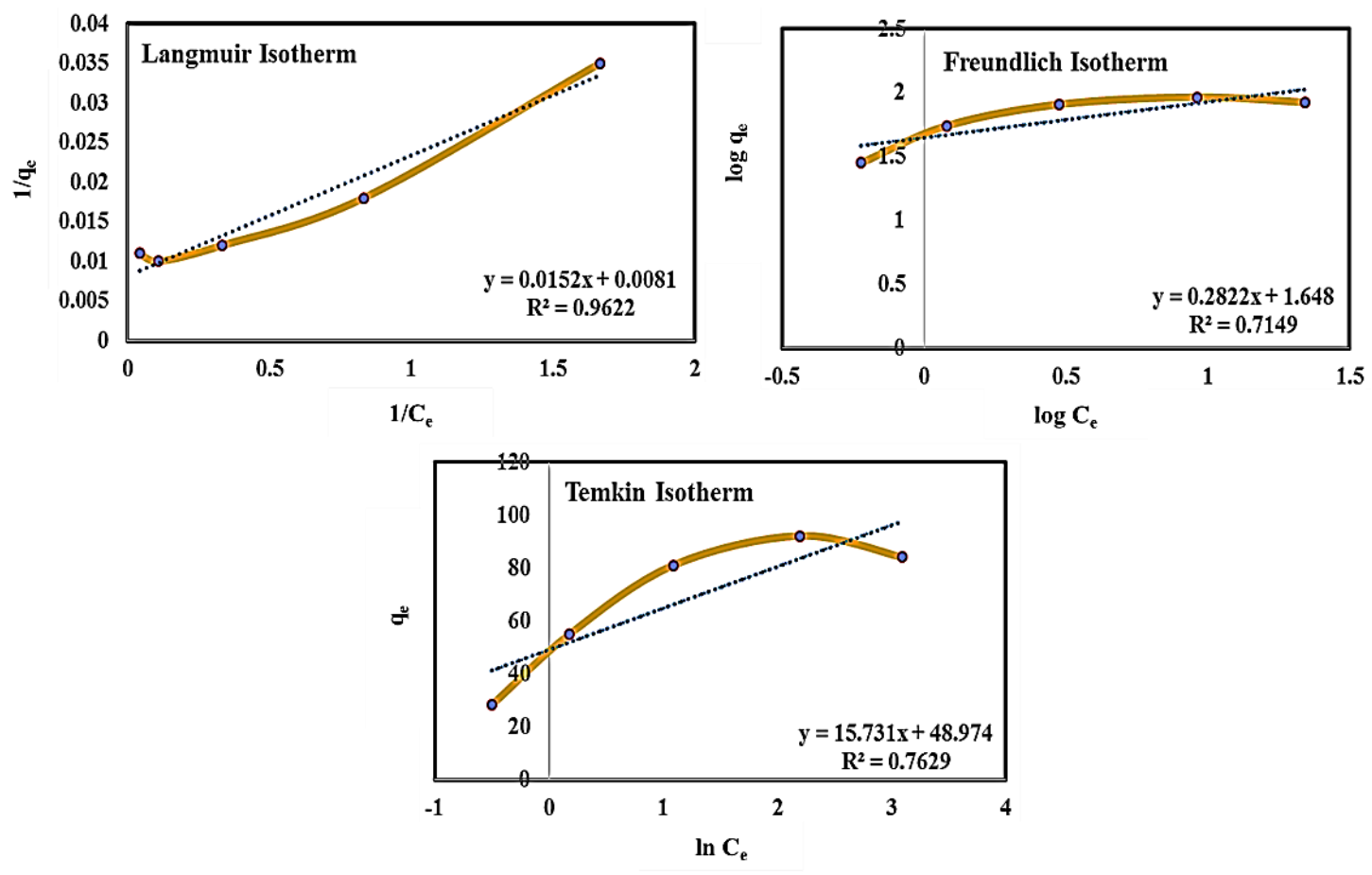

Fig. 12. Parameters obtained from Langmuir, Freundlich, and Tamkin isotherms

\subsection{Thermodynamic results of cefazolin adsorption}

The thermodynamic values for the adsorption of cefazolin drug onto MGAC have been calculated using equations 14-16. The outcomes are summarized in table $6 . \Delta \mathrm{H}^{\circ}, \Delta \mathrm{S}^{\circ}$, and $\Delta \mathrm{G}^{\circ}$ values have been determined as negative for studied three temperatures 303,313 and $323 \mathrm{~K}$. The negative values of $\Delta \mathrm{G}^{\circ}$ display that the adsorption process onto the nanocarrier is spontaneous. The negative values of $\Delta \mathrm{H}^{\circ}$ indicated that the adsorption of cefazoline onto the nanocarrier is an exothermic process. The $\Delta \mathrm{S}^{\circ}$ values play a vital function in reflecting whether the order of adsorbate throughout the adsorption process will become less random $\Delta S^{\circ}<0$ or more random $\Delta \mathrm{S}^{\circ}>0$. Furthermore, the negative $\Delta \mathrm{S}^{\circ}$ value includes reducing in the degree of freedom of cefazolin drug inside the solution. Additionally, the sign of $\Delta \mathrm{S}^{\circ}$ suggests whether or not the adsorption reaction is an associative or dissociative process. So, due to the fact $\Delta \mathrm{S}^{\circ}$, has a negative cost, it is able to be an associative mechanism (Aregawi and Mengistie 2013). According to the value $\Delta \mathrm{H}^{\circ}(-124.095 \mathrm{KJ} / \mathrm{mol})$, the adsorption between the drug and nanocarrier could be categorized as chemical adsorption. Chemical adsorption is based on strong reactions between the adsorbate and the surface sites of the adsorbent.

$$
\begin{aligned}
\ln K & =-\frac{\Delta H^{0}}{R T}+\frac{\Delta S^{0}}{R} \\
\Delta G^{0} & =-R T \ln K
\end{aligned}
$$




$$
\Delta G^{0}=\Delta H^{0}-T \Delta S^{0}
$$

In dilute solutions, thermodynamic constants are defined for adsorption reactions as follows:

$$
K=\frac{q_{e}}{C_{e}}
$$

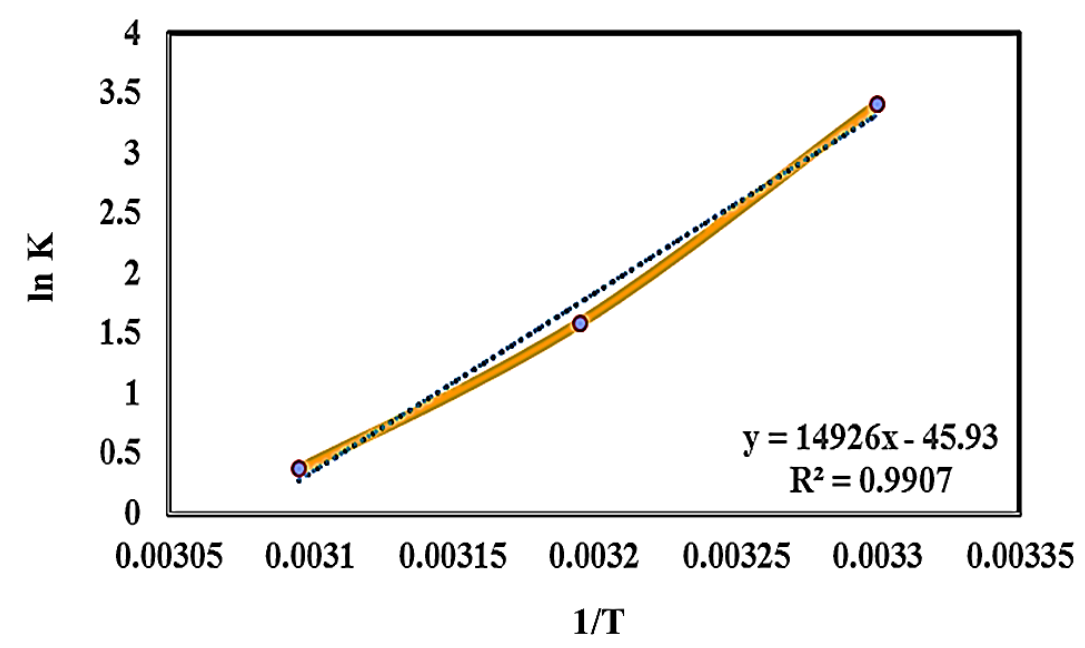

Fig. 13. Relationship between thermodynamic constants and temperature of cefazolin onto nanocarrier.

Table 6. Thermodynamic parameters for the adsorption of cefazolin drug onto MGAC at different temperatures.

\begin{tabular}{|c|c|c|c|c|}
\hline Temp. $(\mathrm{K})$ & $\ln \mathrm{k}$ & $(\mathrm{kj} / \mathrm{mol}) \Delta \mathrm{G}^{\mathrm{O}}$ & $(\mathrm{kj} / \mathrm{mol}) \Delta \mathrm{H}^{\mathrm{O}}$ & $(\mathrm{kj} / \mathrm{mol} . \mathrm{K}) \Delta \mathrm{S}^{0}$ \\
\hline 303 & 3.41 & -8.349 & -124.095 & -0.382 \\
\hline 313 & 1.59 & -4.529 & & \\
\hline 323 & 0.37 & -0.709 & & \\
\hline
\end{tabular}

\subsection{Investigation of the antibacterial effects}

In this research, after characterization of newly synthesized nanocomposite, it is potential as an antibacterial agent against two gram-positive bacteria Streptococcus (1768: S.agalactiae PTCC), and gram-negative bacteria, Salmonella (1609: S.typhi PTCC), was investigated. The antimicrobial properties of MGAC were investigated at three temperatures of 30, 40, and 50 ${ }^{\circ} \mathrm{C}$. The MIC and MBC amounts of the obtained samples are shown in Table (2) and Fig. S3. As can be seen from Table 4. The MIC for Streptococcus and Salmonella is the same at all temperatures and is equal to $500 \mu \mathrm{g} / \mathrm{ml}$. On the other hand, the amount of $\mathrm{MBC}$ for Streptococcus bacteria at 30 and $50{ }^{\circ} \mathrm{C}$ is 1000 and at $40{ }^{\circ} \mathrm{C}$ more than $1000 \mu \mathrm{g} / \mathrm{ml}$ and for Salmonella bacteria at all three temperatures is more than $1000 \mu \mathrm{g} / \mathrm{ml}$. From these values, it can be concluded that the MGAC has an effect on both bacteria and the best concentration of $\mathrm{MBC}$ and MIC is related to the sample at $50{ }^{\circ} \mathrm{C}$ against Streptococcus bacteria. 
Table 4. MIC and MBC values of prepared nanocomposites at different temperatures.

\begin{tabular}{cc|cc|cc}
\hline & \multicolumn{2}{c|}{$\begin{array}{c}\text { S.agalactiae } \\
\text { (Streptococcus) }\end{array}$} & \multicolumn{2}{c}{$\begin{array}{c}\text { S.typhi } \\
\text { (Salmonella) }\end{array}$} \\
\cline { 3 - 6 } & MBC & MIC & MBC & MIC \\
\hline \multirow{3}{*}{ Temp. ( } & A: 30 & $1000^{\mathrm{a}}$ & $500^{\mathrm{b}}$ & $>1000$ & 500 \\
\cline { 2 - 6 } & B: 40 & $>1000$ & 500 & $>1000$ & 500 \\
\cline { 2 - 6 } & C: 50 & 1000 & 500 & $>1000$ & 500 \\
\hline
\end{tabular}

$\mathrm{a} \& \mathrm{~b}$ Concentration unit is $\mu \mathrm{g} \mathrm{mL}^{-1}$

\section{Conclusions}

In This study, a magnetically activated carbon adsorbent was prepared by the green method from flaxseed oil waste. The properties of the prepared nanocomposite were investigated using various analyzes and the results of the analyzes showed that the deposition of $\mathrm{Fe}_{3} \mathrm{O}_{4}$ nanoparticles on the surface of activated carbon was successful. The prepared adsorbent was used for remove of cefazolin from aqueous solutions. To determine the optimal process conditions and achieve maximum efficiency, the effect of temperature, contact time, initial concentration of the drug, composite dosage, and $\mathrm{pH}$ factors was investigated using the response surface method (RSM) and CCD model by DOE software. The results showed that $\mathrm{pH}=6$, temp. $=30{ }^{\circ} \mathrm{C}$, contact time $=150$ minutes, initial concentration of drug $=20 \mathrm{mg} / \mathrm{l}$ and composite dosage $=0.01 \mathrm{~g}$ were the best conditions for removing cefazolin $(96 \%)$ from aqueous medium. Also, the Langmuir, Freundlich, and Temkin isotherms were studied and the results showed that the absorption behavior is most consistent with the Langmuir isotherm. The results of thermodynamic experiments also showed that the adsorption process is exothermic and spontaneous. Finally, the antibacterial properties of the $\mathrm{Fe}_{3} \mathrm{O}_{4} / \mathrm{AC}$ nanocomposite were investigated and the results showed that nanocomposite has antibacterial properties.

\section{Acknowledgment}

The authors express their appreciation to the post-graduate office of Ayatollah Borujerdi University for financial support of this work.

\section{Refrences}

[1] E.S. Elmolla, M. Chaudhuri, J. Hazard. Mater. 173, 445 (2010).

[2] H. Abbasian, M. Hajimolaali, A. Yektadoost, S. Zartab1, J. Res. Phram. Pract. 8, 162 (2019).

[3] F.I. Turkdogan, K. Yetilmezsoy, J. Hazard. Mater. 166, 297 (2009).

[4] Y.Y. Gurkan, N. Turkten, A. Hatipoglu, Z.O. Cinar, Chem. Eng. J. 184, 113 (2012).

[5] W.H. Xu, G. Zhang, S.C. Zou, X.D. Li, Y.C. Liu, Environ. Pollut. 145, 672 (2007). 
[6] A.R. Sayadi Anari, M. Asadpour, Z. Shabani, M.H. Sayadi Anari, J. Rafsanjan Univ. Med. Sci. 11, 11 (2013).

[7] Z. Fang, J. Chen, X. Qiu, W. Cheng, L. Zhu, Journal of Environmental Health Science \& Engineering, 12, 1 (2014).

[8]. A. H. Oliver, N. Voulvoulis, N.L. John, Bull. W. H. O. 81, 768 (2003).

[9] A. Yazdanbakhsh, A., Sheykhmohammadi, M. Sardar, M., Manshori, Journal of Yafteh, 13, 7 (2011) 7. (Persian).

[10] L. Yun, L. Shu-jie, C. Fu-ming, Z. Jian-e, J. Chem. Eng. Data, 64, 5469 (2019).

[11] A. Saffar, H. Abbastabar Ahangar, S. Salehi, M.H. Fekri, A. Rabbani, J. Sol-Gel Sci. Technolo. (JSST), 99, 158 (2021).

[12] A. Azari, B. Kakavandi, R.R. Kalantary, E. Ahmadi, M. Gholami, Z. Torkshavand, M. Azizi, J. Porous Mater. 22 (2015).

[13] M. Razavi Mehr, M.H. Fekri, F. Omidali, N. Eftekhari, B. Akbari-adergani, J. Chem. Health Risks, 9, 75 (2019).

[14] M.H. Fekri, M. Banimahd Keivani, M., Razavi Mehr, B. Akbari-adergani, J. Mazandaran Univ. Med. Sci. 29, 166 (2019).

[15] M.H. Fekri, M. Banimahd keivani, M., Darvishpour, M. Banimahd keivani, Journal of Physical \& Theoretical Chemistry, 9, 95 (2012).

[16] H. Dashti Khavidaki, M.H. Fekri, J. Adv. Chem. 11, 3777 (2015).

[17] E.K. Pasandideh, B. Kakavandi, S. Nasseri, A.H. Mahvi, R. Nabizadeh, A. Esrafili, R.R. Kalantary, J. Environ. Health Sci. Eng. 14, 1 (2016).

[18] X. Jun, L. Sisi, W. Feng, Y. Zhouxiaoshuang, L. Hui, J. Chem. Eng. Data, 64, 1816 (2019).

[19] O. Uner, G. Unal Gec, B. Yuksel, Arabian J. Chem. 12, 1878 (2015).

[20] K. Kummerer, Chemosphere, 75, 417 (2009).

[21] A. Abdollahiasl, A., Kebriaeezadeh, S. Nikfar, A. Farshchi, G. Ghiasi, M. Abdollahi, Int. j. antimicrob. Agents. 37, 489 (2010).

[22] M.H. Fekri, F. Tousi, R. Heydari, M. Razavi Mehr, M., Rashidipour, Iranian Journal of Chemistry and Chemical Engineering (IJCCE), 2021 (in press). DOI: 10.30492/ijcce.2021.128507.4164.

[23] M. Mansour Lakouraj, R.S. Norouzian, S. Balo, J. Chem. Eng. Data, 60, 2262 (2015).

[24] A. Sengupta, R. Rao, D. Bahadur, ACS Sustainable Chem. Eng. 5, 1280 (2017).

[25] E. Altıntıg, H. Altundag, M. Tuzen, A. Sarı, Eng. Res. Des. 122, 151 (2017).

[26] Y. Qian, F. Aiping, L. Hongliang, L., Hui, L., Rui, L., Jingquan, G. Peizhi, Z. Xiu Song, Colloids Surf. A, 457, 288 (2014).

[27] R. A. Rao, R.A. F. Rehman, J. Hazard. Mater. 181, 405 (2010). 



\section{Supplementary Files}

This is a list of supplementary files associated with this preprint. Click to download.

- S.docx 